\title{
PELINDUNGAN TERHADAP WARGA NEGARA INDONESIA SEBAGAI KORBAN TINDAK PIDANA TERORISME DI LUAR NEGERI
}

\section{Susilaningtias}

Wakil Ketua Lembaga Perlindungan Saksi dan Korban (LPSK) susi.encust@gmail.com

\begin{abstract}
ABSTRAK: Pemerintah menerbitkan peraturan yeng mengatur tentang perlindungan terhadap Warga Negara Indonesia (WNI) yang menjadi korban tindak pidana terorisme di luar negeri. Mereka memiliki hak yang sama dengan korban tindak pidana terorisme di dalam negeri. Sehingga tentu pemenuhan hak-haknya akan menemui berbagai tantangan mengingat pemenuhan dapat dilakukan baik ketika mereka kembali ke Indonesia dan/atau di negara setempat terjadinya tindak pidana terorisme, yang tentu memiliki system hukum yang berbeda. Lebih lanjut pemenuhan ini juga tentu akan dibatasi dengan relasi-relasi diplomatic yang harus diterapkan seperti dituangkan di dalam Konvensi Wina. Selain itu, jika muncul perbedaan pandangan antara Indonesia dan negara setempat mengenai suatu peristiwa dapat dikategorikan sebagai tindak pidana terorisme atau tidak, hukum mana yang akan diterapkan. Tantangan ini berpotensi muncul karena sampai detik ini PBB gagal merumuskan definisi terorisme karena perbedaan pandangan di antara negara-negara anggotanya. Dalam semua tantangan dan keterbatasan tersebut, lalu bagaimana rentang tanggung jawab negara untuk memberikan pelindungan kepada WNI yang menjadi korban tindak pidana terorisme di luar negeri.
\end{abstract}

Keyword : Perlindungan Hukum, Warga Negara Indonesia, Tindak Pidana Terorisme

ABSTRACT: The government issued a regulation that regulates the protection of Indonesian citizens (WNI) who are victims of criminal acts of terrorism abroad. They have the same rights as victims of criminal acts of terrorism in the country. So of course the fulfillment of their rights will encounter various challenges considering that fulfillment can be done either when they return to Indonesia and / or in the local country the occurrence of criminal acts of terrorism, which of course has a different legal system. Furthermore, this fulfillment will of course be limited by diplomatic relations which must be implemented as stated in the Vienna Convention. In addition, if there is a difference in views between Indonesia and the local state 
regarding an event that can be categorized as a criminal act of terrorism or not, which law will be applied. This challenge has the potential to arise because until now the UN has failed to formulate a definition of terrorism due to differences in views among its member states. In all these challenges and limitations, then what is the scope of the state's responsibility to provide protection to Indonesian citizens who are victims of criminal acts of terrorism abroad.

Keyword: Legal Protection, Indonesian Citizens, Crime of Terrorism

\section{PENDAHULUAN}

Pada Juli 2020 yang lalu, Presiden Republik Indonesia Joko Widodo menandatangani Peraturan Pemerintah Nomor 35 tahun 2020 tentang Perubahan Atas Peraturan Pemerintah Nomor 7 tahun 2018 tentang Pemberian Kompensasi, Restitusi, dan Bantuan Kepada Saksi dan Korban. ${ }^{1}$ Peraturan ini mengatur mengenai mekanisme pemberian kompensasi, restitusi, dan bantuan bagi saksi dan korban tindak pidana. Peraturan ini merupakan peraturan yang pertama kali mengatur mengenai penanganan terhadap Warga Negara Indonesia (WNI) sebagai korban tindak pidana terorisme di luar negeri. Dalam peraturan ini, WNI yang menjadi korban tindak pidana terorisme di luar negeri berhak mendapatkan bantuan rehabilitasi medis, psikologis, psikososial, dan restitusi atau kompensasi. Lebih lanjut peraturan ini mengatur bahwa hak-hak tersebut dapat diperoleh baik ketika korban berada di luar negeri dan/atau sekembalinya ke tanah air. Adapun lembaga yang ditunjuk untuk melaksanakan pemenuhan hak-hak tersebut adalah Lembaga Perlindungan Saksi dan Korban (LPSK)

Menurut juru bicara Presiden bidang hukum Dini 2Shanti Purwono, bahwa pengaturan mengenai pelindungan trehadap WNI yang menjadi korban tindak pidana terorisme di luar negeri di dalam Peraturan Pemerintah ini adalah wujud komitmen Presiden Jokowi terhadap WNI yang menjadi korban pelanggaran HAM yang berat dan tindak pidana terorisme di luar negeri. Lebih lanjut menurutnya pemerintah memahami kesulitan dan kesedihan pihak keluarga yang

${ }^{1}$ https:// www.hukumonline.com/berita/baca/1t5f226379df52a/ini-hak-wniyang-jadi-korban-terorisme-di-luar-negeri/, diakses terakhir oleh penulis pada tanggal 29 Oktober 2020.

2 Ibid., 


\section{Pelindungan Terhadap Warga Negara Indonesia Sebagai Korban Tindak Pidana Terorisme Di Luar Negeri}

menjadi korban dalam aksi terorisme. Karenanya, Peraturan Pemerintah ini diperbarui untuk meringankan beban keluarga korban dari sisi ekonomi.

Selain itu langkah maju dari Pemerintah Indonesia ini dapat dibaca, bahwa pengaturan ini muncul karena adanya peristiwaperistiwa aksi terorisme di luar negeri yang menjadikan WNI sebagai korbannya. Sebut saja peristiwa penembakan di Masjid Al Noor di pusat Kota Christchurch, Selandia Baru pada Maret 2019, dimana ada 1 orang WNI yang meninggal dunia dan 2 (dua) orang lainnya terluka akibat serangan tersebut. ${ }^{3}$ Belum lagi aksi teror di bandara Brussels pada Maret 2016 yang membuat 3 orang WNI terluka. ${ }^{4}$ Belum lagi beberapa peristiwa penyanderaan WNI oleh kelompok Abu Syayyaf di Filipina. ${ }^{5}$

Secara terpisah salah seorang pejabat di Direktorat Perlindungan WNI dan BHI Kementerian Luar Negeri menyampaikan bahwa WNI yang berada di luar negeri dan tercatat secara resmi itu jumlahnya banyak. Jumlahnya adalah 2.862.495 orang yang terdaftar di dalam e-perlindungan. Sedangkan untuk yang undocumented/overstayer sejumlah 1.870.060. Lebih lanjut, bahwa 98,9\% dari total jumlah tersebut adalah Pekerja Migran Indonesia (PMI), dan 0,58\% adalan Non-PMI (pelajar, mahasiswa, dll.), serta 0,64\% adalah ABK. Jumlah yang banyak ini menunjukkan bahwa memang WNI memiliki potensi yang besar menghadapi ancaman aksi terorisme di luar negeri. ${ }^{6}$

Namun demikian pengaturan mengenai ini masih menimbulkan perdebatan di antara para praktisi karena ternyata tidak semua negara mengenal dan menggunakan istilah tindak

${ }^{3}$ https://www.bbc.com/indonesia/dunia-47578604, diakses terkahir oleh penulis pada tanggal 29 Oktober 2020.

4 https://www.cnnindonesia.com/internasional/20160323113522-134-

119223 /wni-jadi-korban-luka-dalam-ledakan-di-brussels, diakses terakhir oleh penulis pada 29 Oktober 2020.

${ }^{5}$ https://regional.kompas.com/read/2020/10/11/22143121/jenazah-wnikorban-sandera-abu-sayyaf-disambut-tangis-keluarga?page=all, diakses terakhir oleh penulis pada 29 Oktober 2020.

${ }^{6}$ Duta Besar Bambang Antarikso, Perkembangan dan Tantangan Pelindungan WNI di Luar Negeri dari Terorisme, presentasi disampaikan di dalam Rapat Koordinasi yang diselenggarakan oleh BNPT tentang Analisis dan Evaluasi Pelaksanaan

Pelindungan WNI di Luar Negeri dari Ancaman Terorisme, pada 26 Oktober 2020 di Malang. 
pidana terorisme. Ada yang menggunakan violent extremism, dan sebagainya. Lebih lanjut kemudian mengenai bagaimana jika suatu aksi terorisme itu tidak dikategorikan sebagai aksi terorisme oleh hukum negara setempat, sementara menurut hukum Indonesia, peristiwa itu sebagai tindak pidana terorisme. Misalnya, kelompok Abu Syayyaf, oleh Pemerintah Filipina tidak dikategorikan sebagai kelompok terorisme, hanya sebagai perompak. Sehingga aksi-aksinya tidak dapat dikategorikan sebagai tindak pidana terorisme, dan korbannya tidak bisa disebut sebagai korban tindak pidana terorisme. Sementara di sisi lain, otoritas internasional menyatakan bahwa kelompok Abu Syayyaf dikategorikan sebagai kelompok terorisme. Situasi ini tentu membingungkan karena tentu akan sulit menentukan, hukum mana yang akan dipakai untuk mengidentifikasi seseorang itu sebagai korban tindak pidana terorisme atau bukan.

Situasi ini kemudian menarik penulis untuk mengkajinya lebih jauh dengan melihat dalam perspektif hukum Indonesia dan hukum internasional. Kajian ini tentu akan melihat juga dalam teori di dalam victimilogi maupun teori di dalam perjanjian internasional. Selanjutnya hasil kajian ini akan mengahsilkan rekomendasirekomendasi yang diharapkan dapat membantu Pemerintah Indonesia untuk mengambil langkah-langkah untuk menyelesaiakan problem hukum ini, agar para WNI yang menjadi korban tindak pidana terorisme mendapatkan hak-hak nya sesuai dengan ketentuan yang berlaku.

\section{Definisi Mengenai Terorisme Menurut Hukum Internasional dan Hukum Indonesia}

Secara internasional sampai detik ini belum ada kesepakatan mengenai definisi tentang terorisme. ${ }^{7}$ Namun demikian, In Resolution 1566, adopted unanimously in 2004, the Security Council described terrorism as:

Criminal acts, including against civilians, committed with the intent to cause death or serious bodily injury, or taking of hostages, with the purpose to provoke a state of terror in the general public or in a group of

7 Alastair Reed, Jeanine de Roy van Zuijdewijn and Edwin Bakker, Pathways of Foreign Fighters: Policy Options and Their (Un)Intended Consequences, ICCT Policy Brief, The Hague, April 2015, hlm. 8-10. 
persons or particular persons, intimidate a population or compel a government or an international organization to do or to abstain from doing any act, which constitute offences within the scope of and as defined in the international conventions and protocols relating to terrorism.

Sedangkan Undang-undang Nomor 5 tahun 2018 tentang Perubahan Atas Undang-undang Nomor 15 tahun 2003 tentang Pengesahan Peraturan Pemerintah Pengganti Undang-undang Nomor 1 tahun 2002 tentang Pemberantasan Tindak Pidana Terorisme menjadi Undang-undang, memberikan definisi tindak pidana terorisme sebagai berikut:

Terorisme adalah perbuatan yang menggunakan kekerasan atau ancaman kekerasan yang menimbulkan suasana teror atau rasa takut secara meluas, yang dapat menimbulkan korban yang bersifat massal, dan/atau menimbulkan kerusakan atau kehancuran terhadap objek vital yang strategis, lingkungan hidup, fasilitas publik, atau fasilitas internasional dengan motif ideologi, politik, atau gangguan keamanan.

\section{Kerangka Teori}

\section{Teori Viktimologi}

Perspektif viktimologi dalam mengkaji korban memberikan orientasi bagi kesejahteraan masyarakat, pembangunan kemanusiaan masyarakat, dalam upayanya untuk menjadikan para anggota masyarakat tidak menjadi korban dalam arti luas. Sebagaimana dikemukakan oleh Mendelsohn, bahwa: ..."that victimology should be a separate and autonomous sciences, should have its own institutions and should be allowed to develop for the well-being and progress of humanity. Hal ini sejalan pula dengan pemikir viktimologi seperti Ellias ataupun Separanovic memberikan kajian viktimologi untuk mengedepankan wawasan hak asasi manusia maupun dari sisis penderitaan manusia/human suffering guna lebih mengekspresikan the rights of life, freedom and security. Studi korban dalam viktimologi memberikan suatu gagasan bidang jelajah dalam viktimologi, yaitu:

a. Konteks social yang menjadi tempat terjadinya viktimisasi. Konteks social menunjuk pada nilai-nilai kultural tradisi dan struktur yang mempengaruhi perbedaan, kedudukanm status individua atau kelompok seperti tekanan social, konflik, cap jahat, dan ketidakseimbangan structural antara tujuan dan cara 
dari system social, peluang untuk melakukan jalan lain untuk memakai cara-cara yang tidak legal dan untuk "differential association", serta cara-cara penyelesaian konflik.

b. Akibat-akibat social dari viktimisasi yang dapat berpengaruh buruk terhadap individu, kelomok, masyarakat luas, maupun kemanusiaan pada umumnya, baik secara medis, psikiatri, kriminologi maupun implikasi social. ${ }^{8}$

Selanjutnya dalam rangka pengaturan hukum pidana terhadap korban kejahatan secara mendasar dikenal dua model, yaitu model hak-hak procedural (procedural rights) dan model pelayanan (service model). Pada model pertama, penekanan diberikan pada dimungkinkannya korban untuk memainkan peranan aktif, dalam proses criminal atau dalam jalannya proses peradilan. Dalam hal ini, korban korban dilihat sebagai subyek yang harus diberi hak-hak juridis yang luas untuk menuntut dan mengejar kepentingannya. Sedangkan pada model layanan, penekanan diletakkan bahwa korban kejahatan sebagai sarana khusus untuk dilayani dalam kerangka kegiatan para penegak hukum. ${ }^{9}$

\section{Teori Hukum Perjanjian Internasional}

Menurut J.G. Starke, hukum internasional adalah keseluruhan hukum yang sebagian besar tediri dari prinsipprinsip dan kaidah-kaidah perilaku, yang terhadapnya negaranegara merasa dirinya terikat untuk mentaati dan karenanya benar-benar ditaati secara umum dalam hubungan satu sama lainnya. Dari definisi J.G. Starke di atas, terutama pada huruf (b), jelas bahwa hukum internasional mencakup hak-hak dan kewajiban individu sepanjang hal tersebut penting bagi masyarakat internasional. J.G.Starke menguraikan bahwa sumbersumber materiil hukum internasional dapat didefenisikan sebagai bahan-bahan aktual yang digunakan oleh para ahli hukum internasional untuk menetapkan hukum yang berlaku bagi suatu peristiwa atau situasi tertentu. Pada garis besarnya, bahan-bahan

${ }^{8}$ Maya Indah S, Perlindungan Korban Suatu Perspektif Viktimologi dan Kriminologi Edisi Kedua, Kencana Prenadamedia Grou, Jakarta, 2016, hlm. 17-19

${ }^{9}$ Siswanto Sunarso, Viktimologi dalam Sistem Peradilan Pidana, Sinar Grafika, Jakarta, 2012, hlm. 79-80 
yang dapat dikatagorikan dalam lima bentuk, yaitu:kebiasaan, traktat, keputusan pengadilan atau badan-badan arbitrase, karyakarya hukum, dan keputusan atau ketetapan organorgan/lembaga internasional.

Berkaitan dengan perjanjian internasional, berlaku prinsip atau asas pacta sunt servanda sebagaimana diatur di dalam Pasal 26 Konvensi Wina 1969. Prinsip ini berakar dari tradisi YunaniRomawi Kristen dan di tradisi budaya agama lainnya. ${ }^{10}$ Menurut prinsip ini bahwa setiap treaty atau perjanjian berlaku dan memiliki kekuatan hukum dan harus dilaksanakan dengan itikad baik (good faith). Lebih lanjut Lung-Chu Chen menyampaikan : "Pacta sunt servanda is indispensable to the commion interest in establishing and maintaining the stability of expectation for all parties concerned. Stable internasional relations depend on the ability of states to put faith in one another's expressed intent to fulfil treaty commitments. ${ }^{11}$

Pada umumnya perjanjian internasional hanya dapat diberlakukan kepada negara anggotanya, atau dengan kata lain tidak dapat diberlakukan kepada negara ketiga sebagaimana diatur di dalam Pasal 2 ayat (1) dan 34 Konvensi Wina 1969. Hal ini sesuai dengan prinsip hukum pacta tertiis nec nocent nec prosunt, yang berarti bahwa suatu perjanjian tidak berlaku bagi pihak ketiga, kecuali jika negara ketiga memberikan persetujuannya atas pemberlakuan perjanjian internasional tersebut.

Dalam hal ini bahwa negara memiliki kebebasan untuk melakukan perjanjian internasional, tetapi negara diberikan kewajiban untuk melaksanakan perjanjian tersebut dengan itikad baik. Dengan kata lain, perjanjian internasional ini menjadi hukum bagi negara-negara pihak yang menjadi anggota dalam perjanjian tersebut.

\section{Hukum Internasional Mengenai Hak-Hak Korban Kejahatan}

${ }^{10}$ Lung-Chu Chen, An Introduction to Contemporary International Law, A PolicyOriented Perspective (Second Edtition), Yale University Press, New Haven dan London, 2000, hlm. 266-267.

11 Ibid, hlm. 267 
Pada awalnya system peradilan pidana hanya berorientasi kepada perlindungan terhadap pelaku kejahatan dan pemenuhan terhadap hak-haknya. Sementara saksi dan korban yang memiliki peran penting dalam mengungkap kejahatan, justru pada saat itu belum banyak diperhatikan. Sejak tahun 1970-an keberadaan dan peran saksi di dalam system peradilan pidana mulai banyak dikaji. Saat itu korban kejahatan dinilai sebagai "pihak yang dilupakan" karena tidak ada perlindungan dan jaminan terhadap hak-hak korban kejahatan. ${ }^{12}$

Perhatian terhadap korban kejahatan dan hak-haknya muncul sejak Kongres PBB Vll/1985 di Milan tentang "The Prevention of Crime and the Treatment of Offenders", yang mengemukakan bahwa hak-hak korban seharusnya terlihat sebagai bagian yang tak terpisahkan dari sistem peradilan pidana ("victims rights should be perceived as an integral aspect of the total criminal justice system"). Kemudian dilanjutkan dengan lahirnya Declaration of basic principles ofjustice for victims of crime and abuse of power" pada tanggal 6 September 1985 yang memberikan pengertian "korban". Menurut deklarasi ini, "Victims" means persons who, individually or collectively, have suffered harm, including physical or mental injury, emotional suffering, economic loss or substantial impairment of their fundamental right, through acts or omissions that are in violation of criminal laws operative within member states, including those laws proscribing criminal abuse power". Perhatian ini dilandasi oleh adanya perkembangan pemikiran mengenai keadilan (restorative jtustice), yang beralih orientasi dari perhatian terhadap hak-hak pelaku kejahatan kepada pehatian terhadap korban kejahatan.

Deklarasi ini memang tidak menyebutkan secara eksplisit mengenai korban tindak pidana terorisme, tetapi deklarasi ini mengatur hak-hak korban kejahatan secara umum. Sehingga dapat pula diberlakukan kepada korban terorisme. Deklarasi ini juga belum mengatur mengenai perlindungan kepada saksi kejahatan.

Selanjutnya pada tahun 2000, negara-negara di dunia bersepakat untuk menandatangani United Convention on

12 The Criminal Justice Response to Support Victims of Acts of Terrorism Revised Edition, UNODC, New York, 2012, hlm. 4 
Transnational Organized Crime. Konvensi ini merupakan hard law pertama yang mengatur mengenai perlindungan kepada saksi beserta keluarganya dan pemenuhan atas hak-hak korban kejahatan. Konvensi ini mengatur berbagai hal seperti; ruang lingkup kejahatan transnational organized crime, langkah negaranegara pihak untuk melakukan penegakan hukum terhadap kelompok terorganisir yang menjadi pelaku kejahatan, langkah negara-negara pihak untuk memerangi kejahatan ini (seperti korupsi, pencucian uang, dsb), ekstradisi, sampai kepada perlindungan terhadap saksi beserta keluarganya dan bantuan kepada korban kejahatan. Indonesia merupakan salah satu negara pihak dalam konvensi ini dan telah meratifikasi konvensi ini melalui Undang-undang Nomor 5 tahun 2009 tentang Pengesahan United Nations Convention Against Transnational Organized Crime (Konvensi Perserikatan Bangsa-Bangsa Menentang Tindak Pidana Transnasional Terorganisasi).

Pengaturan mengenai perlindungan terhadap saksi kejahatan transnasional terorganisasi diatur di dalam Artikel 24 dalam konvensi ini. Disebutkan di dalam artikel ini mengenai rekomendasi langkah-langkah yang dapat diambil oleh negaranegara pihak, seperti perlindungan fisik, relokasi dan kerahasiaan identitas saksi. Lebih lanjut direkomendasikan untuk negaranegara pihak melakukan perjanjian dengan negara lain untuk relokasi bagi saksi yang dilindungi. Sedangkan mengenai asistensi dan bantuan kepada korban kejahatan diatur di Artikel 25. Artikel ini mensyaratkan Negara-negara Pihak untuk menetapkan prosedur untuk memberikan akses ke kompensasi dan restitusi bagi para korban.

\section{Hukum Indonesia tentang Hak-Hak Korban Kejahatan}

Tidak berbeda dengan perkembangan di dunia internasional, di Indonesia pada awalnya kedudukan korban kejahatan dalam sistem peradilan pidana kurang diperhatikan. Awalnya fokus perhatian lebih ditujukan kepada hak-hak pelaku kejahatan. Hal ini dapat terlihat di dalam Kitab Undang-undang Hukum Acara Pidana, dimana ketentuan mengenai hak-hak pelaku diatur sangat detail, sedangkan mengenai korban tidak diatur banyak serta tidak diatur secara tegas dan detail. 
Kepentingan korban kejahatan saat itu hanya diwakili oleh jaksa penuntut umum. Terkait dengan hak-hak korban kejahatan KUHAP hanya mengatur mengenai ganti rugi rehabilitasi bagi korban salah tangkap dan penggabungan perkara bagi ganti rugi korban. Ketentuan tentang ini diatur di dalam Pasal 98 dan Pasal 99 Undang, undang Nomor 8 tahun 1991 tentang Kitab Undang,, undang Hukum Acara Pidana. Namun seiring dengan perkembangan pemikiran mengenai konsep-konsep keadilan yang salah satunya meletakkan perhatian kepada kepentingan korban kejahatan, maka kemudian muncul beberapa peraturan perundangundangan yang di dalam ketentuannya mengatur mengenai hak-hak korban kejahatan, dimulai dengan Undangundang Nomor 26 tahun 2000 tentang Pengadilan HAM. Kemudian diikuti berbagai peraturan yang di dalam ketentuannya mengatur mengenai dukungan bagi korban kejahatan yakni :

a. Undang w Undang No. 23 Tahun 2002 tentang Perlindungan Anak yang diubah dengan Undang-Undang Nomor 35 tahun 2014 tentang Perubahan Atas Undang-Undang Nomor 23 tahun 2002 tentang Perlindungan Anak;

b. Undang-Undang No. 15 Tahun 2003 tentang Terorisme dan Peraturan Pemerintah Nomor 24 tahun 2003 tentang Tata Cara Perlindungan terhadap Saksi, Penyidik, Penuntut Umum, dan Hakim dalam Perkara Tindak Pidana Terorisme, yang selanjutnya diubah oleh Undang-undang Nomor 5 tahun 2018 tentang Perubahan Atas Undang-Undang Nomor 15 tahun 2003 tentang Pengesahan Peraturan Pemerintah Pengganti Undang-Undang Nomor 1 tahun 2002 Menjadi Undangundang;

c. Undang-Undang No. 15 Tahun 2003 tentang Terorisme dan Peraturan Pemerintah Nomor 24 tahun 2003 tentang Tata Cara Perlindungan terhadap Saksi, Penyidik, Penuntut Umum, dan Hakim dalam Perkara Tindak Pidana Terorisme;

d. Undang-Undang Nomor 13 tahun 2006 tentang Perlindungan Saksi dan Korban yang selanjutnya diubah dengan Undang, undang Nomor 31 tahun 2014.

e. Undang-Undang No 21 Tahun 2007 tentang Pemberantasan terhadap Tindak Pidana Perdagangan Orang; 
f. Undang-Undang No. 22 Tahun 2009 tentang Lalu Lintas; g. Undang-Undang No. 35 Tahun 2009 tentang Narkotika;

Kehadiran Undang-undang Nomor 13 tahun 2006 ini menjadi momentum penting bagi korban kejahatan untuk dapat mengakses pemulihan dan keadilan secara lebih jelas. Hal ini karena di dalam undang-undang tersebut diuraikan secara tegas dan jelas mengenai bentuk-bentuk layanan dan dukungan terhadap korban kejahatan, ketentuan mengenai mekanisme untuk pemberian perlindungan dan bantuan terhadap saksi dan korban kejahatan, kelembagaan yang mengurusi pemenuhan hakhak saksi dan korban, serta ketentuan pidana mengenai perlindungan saksi dan korban.

Namun demikian di dalam praktiknya, pelaksanaan hakhak korban dalam berbagai regulasi ini menemui banyak kendala karena beberapa hal, diantaranya mengenai ketentuannya regulasi masih belum lengkap, sistem layanan korban yang sangat terfragmentasi baik berdasarkan jenis pidana, regulasi dan lembaga penyedia layanan korban. Persoalan orientasi aparat penegak hukum yang belum sepenuhnya memadai dan minimnya akses masyarakat umum, termasuk masyarakat korban atas adanya hak hak korban yang dapat mereka jangkau, dan Iain sebagajnya.

Undang-undang Perlindungan Saksi dan Korban sendiri akhirnya direvisi pada tahun 2014 melalui diundangkannya Undang-undang Nomor 31 tahun 2014 tentang Perubahan Atas Undang-undang Nomor 13 tahun 2006 tentang Perlindungan Saksi dan Korban. Beberapa hal yang terkait dengan dukungan terhadap korban kejahatan, yang diatur di dalam revisi undangundang tersebut, mencakup mengenai: Pertama, adanya beberapa jenis tindak pidana yang secara khusus disebut di dalam undangundang ini, yang korbannya harus mendapatkan pemulihan seperti pelanggaran HAM yang berat, tindak pidana terorisme, tindak pidana perdagangan orang, tindak pidana kekerasan seksual terhadap anak, penyiksaan, dan penganiayaan berat. Kedua, secara khusus di dalam peraturan ini disebutkan bahwa korban tindak pidana terorisme berhak mendapatkan kompensasi dan restitusi, dimana di dalam undang-undang sebelumnya tidak disebutkan mengenai hak atas kompensasi bagi korban tindak 
pidana terorisme. Ketiga, undang-undang ini menambahkan bentuk bantuan psikologis selain bantuan medis dan psikososial yang sebelumnya hanya menyebutkan mengenai bantuan medis dan psikososial. Keempat, undang, undang ini menjelaskan secara detail mengenai konsep bantuan medis, psikologis, dan psikososial di dalam penjelasannya. Kelima, undang-undang ini mengatur mengenai mekanisme pengajuan restitusi dan kompensasi secara Iebih jelas. Keenam, kewenangan LPSK untuk melakukan penilaian ganti rugi dalam pemberian restitusi dan kompensasi bagi korban tindak pidana. Ketentuanketentuan baru di dalam Undang-undang Nomor 31 tahun 2014 ini semakin memperjelas tugas dan kewenangan LPSK serta bagi korban semakin memperjelas untuk dapat mengakses layanan dari LPSK.

\section{Pemenuhan Hak-Hak Korban Tindak Pidana Terorisme di Indonesia}

Pengaturan mengenai hak-hak korban tindak pidana terorisme pertama kali diatur di Indonesia melalui Peraturan Pemerintah Pengganti Undang-undang Nomor 1 tahun 2002 tentang Pemberantasan Tindak Pidana Terorisme, yang selanjutnya disahkan menjadi undang-undang melalui Undang-Undang Nomor 15 tahun 2003. Peraturan ini diundangkan setelah ada peristiwa teror bom di Bali pada bulan Oktober 2002. Menurut peraturan ini, korban tindak pidana terorisme berhak untuk mendapatkan kompensasi atau restitusi. Kompensasi merupakan ganti kerugian yang diberikan kepada korban oleh negara. Sedangkan restitusi merupakan ganti kerugian yang dibayarkan oleh pelaku kepada korban kejahatan. Kedua hak ini harus diputuskan melalui pengadilan agar dapat diberikan kepada korban tindak pidana terorisme.

Namun demikian, faktanya pemenuhan hak atas restitusi dan kompensasi bagi korban terorisme ini sangat minim dilaksanakan. Sejak tahun 2002, baru pada Bulan September tahun 2017 korban tindak pidana terorisme mendapatkan kompensasinya. Saat itu pertama kalinya Pengadilan Negeri Jakarta Timur memutuskan korban tindak pidana terorisme bom di Gereja Samarinda mendapatkan kompensasinya. Jumlah kompensasi yang dibayarkan adalah 237 jutaan rupiah kepada 7 (tujuh) orang korban dan 
keluarganya. ${ }^{13}$ Kemudian berturut-turut korban serangan teror di depan mall Sarinah di Jakarta, bom Kampung Melayu, dan seterusnya.

Jika dilihat dari fakta di atas, ternyata butuh 15 tahun kemudian korban tindak pidana terorisme mulai dipenuhi haknya. Situasi ini seiring dengan telah diterbitkannya Undang-undang Nomor 31 tahun 2014 tentang Perubahan Atas Undang-undang Nomor 13 tahun 2006 tentang Perlindungan Saksi dan Korban. Undang-undang ini menegaskan Kembali hak korban terorisme atas kompensasi atau terorisme, selain juga menambahkan hak-hak baru berupa bantuan rehabilitasi medis, rehabilitasi psikologis, dan psikososial. Undangundang ini mengatur pelaksanaan pemenuhan hak korban atas kompensasi disesuaikan dengan peraturan perundang-undangan tentang pemberantasan tindak pidana terorisme. Selanjutnya menurut undang-undang ini, Lembaga Perlindungan Saksi dan Korban (LPSK) menjadi pihak yang melaksanakan pemenuhan hakhak korban terorisme tersebut.

Namun demikian, dapat dilihat juga bahwa para korban tindak pidana terorisme yang peristiwanya terjadi sejak tahun 2002 hingga peristiwa bom Samarinda, tidak mendapat perhatian dan uluran tangan dari negara secara serius. Atas situasi ini, kemudian para korban turut serta bersuara untuk memperjuangkan agar hak-hak korban tindak pidana terorisme diatur di dalam revisi Undangundang Perlindungan Saksi dan Korban pada tahun 2014. Para korban ini selanjutnya juga turut serta dengan LPSK untuk memperjuangkan revisi Undang-undang Nomor 15 tahun 2003 tentang Pengesahan Peraturan Pemerintah Pengganti Undangundang Nomor 1 tahun 2002 tentang Pemberantasan Tindak Pidana Terorisme. Revisi undang-undang ini baru diundangkan pada tahun 2018 melalui Undang-undang Nomor 5 tahun 2018 tentang Perubahan Atas Undang-undang Nomor 15 tahun 2003 tentang Pengesahan Peraturan Pemerintah Pengganti Undang-undang Nomor 1 tahun 2002 tentang Pemberantasan Tindak Pidana Terorisme. Lebih lanjut Presiden menandatangani Peraturan

${ }^{13}$ Eksekusi putusan Pengadilan Negeri Jakarta Timur dilaksanakan oleh Jaksa dan LPSK pada Bulan Desember 2017 dan telah diumumkan oleh LPSK melalui websitenya https://lpsk.go.id/berita/detailberita/2740, diakses terakhir oleh penulis pada tanggal 29 Oktober 2020. 
Pemerintah Nomor 35 tahun 2020 tentang Perubahan Atas Peraturan Pemerintah Nomor 7 tahun 2018 tentang Pemberian Kompensasi, Restitusi, dan Bantuan Kepada Saksi dan Korban, sebagai pelaksana dari Undang-undang Nomor 5 tahun 2018.

Undang-undang Nomor 5 tahun 2018 dan Peraturan Pemerintah Nomor 35 tahun 2020 ini semakin menegaskan pengaturan hak-hak korban terorisme, baik mengenai bantuan rehabilitasi medis, psikologis, psikososial, santunan bagi keluarga korban yang meninggal dunia, dan termasuk hak atas kompensasi atau restitusi. Undang-undang ini menegaskan bahwa korban tindak pidana terorisme adalah tanggung jawab negara. ${ }^{14}$ Bahkan Undangundang ini juga mengatur mengenai hak-hak korban tindak pidana terorisme masa lalu sebelum diundangkannya Undang-undang Nomor 5 tahun 2018, dan sejak peristiwa Bom Bali I. Sedangkan pengaturan mengenai pelindungan WNI yang menjadi korban tindak pidana terorisme di luar negeri diatur di dalam Pasal 44 I sampai dengan Pasal 44 Q Peraturan Pemerintah Nomor 35 tahun 2020. Selain itu kedua peraturan perundang-undangan ini memandatkan kepada LPSK untuk melaksanakan pemenuhan hak-hak korban tindak pidana terorisme tersebut.

Berdasarkan ketentuan di dalam Pasal 35 A ayat (2) UndangUndang Nomor 5 tahun 2018, disebutkan bahwa korban tindak pidana terorisme yang menjadi tanggung jawab negara, ditetapkan sebagai korban oleh penyidik berdasarkan hasil olah Tempat Kejadian Perkara (TKP). Sehingga agar para korban dapat mengakses hak-haknya, mereka harus dinyatakan terlebih dahulu sebagai korban tindak pidana terorisme oleh penyidik. Namun ini berbeda dengan korban tindak pidana terorisme masa lalu, keterangan mereka sebagai korban dilakukan oleh BNPT (Badan Nasional Penanggulangan Terorisme). Sedangkan untuk WNI yang menjadi korban di luar wilayah Indonesia, diterangkan atau ditetapkan oleh Perwakilan Pemerintah Republik Indonesia di luar negeri.

Selanjutnya menurut siaran pers dari Lembaga Perlindungan Saksi dan Korban (LPSK) pada 25 Agustus 2020 dalam rangka hari peringatan dan penghormatan internasional kepada korban 
terorisme, ${ }^{15}$ menyebutkan bahwa LPSK telah memberikan layanan bantuan kepada korban tindak pidana terorisme sejak tahun 2015. Sejak saat itu LPSK telah memberikan bantuan berupa bantuan rehabilitasi medis, psikologis, psikososial, dan fasilitasi pemenuhan hak atas kompensasi bagi korban terorisme. Menurut catatannya, LPSK telah memberikan pelindungan dan bantuan kepada 489 korban tindak pidana terorisme. Dari 489 orang korban tersebut, terdapat 304 orang korban tindak pidana terorisme masa lalu yang telah dilayani oleh LPSK, dan 185 orang korban tindak pidana pasca diundangkannya Undang-Undang Nomor 5 tahun 2018. Sementara LPSK menyebutkan bahwa sampai detik ini belum memberikan bantuan dan pelindungan terhadap WNI yang menjadi korban tindak pidana terorisme di luar wilayah negara Indonesia.

\section{Pelindungan Bagi WNI Yang Menjadi Korban Tindak Pidana Terorisme di Luar Negeri}

Di atas disebutkan bahwa WNI yang menjadi korban tindak pidana terorisme di luar wilayah negara Republik Indonesia memiliki hak untuk mendapatkan bantuan rehabilitasi medis, psikologis, psikososial, santunan bagi keluarga korban meninggal dunia, dan restitusi atau kompensasi. Hak-hak ini dipenuhi oleh Lembaga Perlindungan Saksi dan Korban (LPSK) setelah korban tindak pidana terorisme diidentifikasi oleh Perwakilan Pemerintah Republik Indonesia di luar negeri melalui penerbitan surat keterangan. Pemenuhan hak-hak saksi dan korban ini dapat dipenuhi Ketika korban di luar negeri, maupun ketika kembali pulang ke Indonesia.

Selain itu dalam hal pemberina bantuan kepada WNI yang menjadi korban tindak pidana terorisme di luar negeri, meskipun dilaksanakan oleh LPSK, juga dikoordinasikan oleh Kementerian yang menyelenggarakan urusan pemerintahan di bidang luar negeri (Kementerian Luar Negeri). Tetapi ketika WNI yang menjadi korban tersebut kembali ke Indonesia dan hendak mendapatkan hak-haknya tersebut, maka para korban atau keluarganya atau kuasa hukumnya mengajukan ke Lembaga Perlindungan Saksi dan Korban (LPSK)

${ }^{15}$ Resolusi Sidang Umum PBB No. 72/165 bulan Juli 2017 menetapkan tanggal 21 Agustus sebagai Hari peringatan dan penghormatan internasional kepada korban terorisme. 
sebagaimana diatur di dalam Pasal 44 J, Pasal 44 K, Pasal 44 L, dan Pasal 44 M Peraturan Pemerintah Nomor 35 tahun 2020.

Selanjutnya, dalam hal di negara tempat terjadinya tindak pidana terorisme tidak menggunakan istilah tindak pidana terorisme, penerbitan surat keterangan oleh Perwakilan Republik Indonesia di luar negeri dapat dilakukan dengan berkoordinasi dengan Badan Nasional Penanggulangan Terorisme (BNPT). Ketentuan mengenai ini diatur di dalam Pasal $44 \mathrm{~J}$ ayat (8), Pasal $44 \mathrm{~K}$ ayat (6), Pasal $44 \mathrm{~L}$ ayat (7), dan Pasal $44 \mathrm{M}$ ayat (7) Peraturan Pemerintah Nomor 35 tahun 2020.

Klausul ini memang telah menentukan jalan keluar terhadap potensi konflik hukum terkait dengan ketentuan tentang penegakan hukum tindak pidana terorisme di Indonesia dan negara setempat terjadinya tindak pidana terorisme. Ketentuan ini jelas mengedepankan kepentingan terbaik bagi WNI yang menjadi korban. Hal ini menunjukkan komitmen Pemerintah Indonesia untuk menerapkan service model dalam teori di dalam ilmu viktimologi. Service model ini ditunjukkan dengan ketentuan mengenai pemenuhan terhadap hak-hak korban kejahatan, yang dalam hal ini adalah pemberian bantuan rehabilitasi medis, psikologis, psikososial, santuan bagi keluarga korban meninggal dunia, dan kompensasi atau restitusi. Menu hak-hak yang disajikan kepada korban adalah murni dalam bentuk pelayanan agar hak-hak korban dipenuhi.

Namun demikian, bentuk pelayanan ini bisa jadi dibatasi oleh teritori negara karena peristiwa nya terjadi di negara lain. Sedangkan Pemerintah Indonesia tidak memiliki otoritas di negara lain. Otoritas di negara lain tentu tidak dapat dipaksakan kecuali dengan hubungan diplomatic atau hubungan internasional. Hubungan internasional dapat dijalin dengan komunikasi dan Kerjasama antar negara baik secara bilateral maupun multilateral. Kerjasama ini merupakan pacta sunt servanda. Maksudnya, menurut prinsip ini bahwa setiap treaty atau perjanjian berlaku dan memiliki kekuatan hukum dan harus dilaksanakan dengan itikad baik (good faith). Sehingga perjanjian menjadi hukum bagi kedua belah pihak yang harus dilaksanakan.

Dalam konteks ini, dengan perjanjian antar negara ini, dapat memudahkan Pemerintah Indonesia dalam hal ini diwakili oleh Kementerian Luar Negeri RI untuk memenuhi hak-hak WNI yang 
menjadi korban tindak pidana terorisme di luar negeri. Selanjutnya, Langkah Pemerintah Republik Indonesia untuk melakukan komunikasi dengan WNI yang menjadi korban termasuk melakukan pemeriksaan-pemeriksaan dapat dilakukan secara bersama kedua belah pihak (negara), yaitu. Negara tempat terjadinya tindak pidana terorisme dan negara Indonesia.

Lebih lanjut, perlu ada mekanisme yang lebih detail untuk teknis pemenuhan hak-hak ini, yaitu dibuatnya kesepakatan bersama antara Kementerian Luar Negeri RI, LPSK, dan BNPT. Ketiga pihak ini harus segera duduk bersama untuk merumuskan mekanisme dan pembagian kerja di antara ketiga lembaga ini agar dapat segera memproses pemenuhan hak-hak WNI yang menjadi korban di luar negeri. Lebih lanjut, ketiga lembaga ini bisa membuka peluang kerjasaama dengan lembaga/instansi lainnya untuk memperlancar proses pemenuhan hak-hak tersebut.

\section{PENUTUP}

Dalam ilmu viktimologi, korban kejahatan seharusnya tidak boleh menjadi korban lagi karena adanya proses yang berbelit dalam upaya pemenuhan hak-haknya sebagai korban. Demikian halnya dengan WNI yang menjadi korban tindak pidana terorisme di luar negeri, harus dihindari mengalami reviktimisasi hanya karena adanya perbedaan penerapan hukum di negara setempat dan negara Indonesia. Dalam hal ini, Pemerintah Indonesia telah menunjukkan komitmennya untuk menghindarkan para kobran dari reviktimisasi dengan cara memandatkan kepada BNPT untuk mengkoordinasikan hal ini. Sehingga memudahkan Kementrian Luar Negeri RI dan LPSK dapat melaksanakan kewajibannya untuk memenuhi hak-hak WNI yang menjadi korban tindak pidan terorisme di luar negeri.

Lebih lanjut Pemerintah Republik Indonesia perlu membuka Kerjasama internasional dengan negara-negara, dimana para WNI berpotensi besar menjadi korban tindak pidana terorisme. Kerjasama ini dapat dibangun untuk memudahkan Pemerintah Indonesia dapat memproses pemenuhan hak-hak korban tersebut. Terakhir, bahwa lembaga-lembaga negara yang memiliki kewajiban untuk melaksanakan pemenuhan hak-hak tersebut, harus melakukan koordinasi dan Menyusun mekanisme yang lebih detail. 
Pelindungan Terhadap Warga Negara Indonesia Sebagai Korban Tindak Pidana Terorisme Di Luar Negeri 


\section{DAFTAR PUSTAKA}

Reed, Alastair. Jeanine de Roy van Zuijdewijn and Edwin Bakker, Pathways of Foreign Fighters: Policy Options and Their (Un) Intended Consequences. ICCT Policy Brief, The Hague, April 2015;

Antarikso, Bambang. Perkembangan dan Tantangan Pelindungan WNI di Luar Negeri dari Terorisme, presentasi disampaikan di dalam Rapat Koordinasi yang diselenggarakan oleh BNPT tentang Analisis dan Evaluasi Pelaksanaan Pelindungan WNI di Luar Negeri dari Ancaman Terorisme. Pada 26 Oktober 2020 di Malang

Chen, Lung-Chu. An Introduction to Contemporary International Law, A Policy-Oriented Perspective (Second Edtition). New Haven dan London: Yale University Press. 2000.

Indah S, Maya. Perlindungan Korban Suatu Perspektif Viktimologi dan Kriminologi Edisi Kedua. Jakarta: Kencana Prenadamedia Group, 2016

Sunarso, Siswanto. Viktimologi dalam Sistem Peradilan Pidana. Jakarta: Sinar Grafika, 2012.

UNODC. The Criminal Justice Response to Support Victims of Acts of Terrorism Revised Edition. New York: UNODC, 2012.

\section{Sumber Internet:}

https:/ / www.hukumonline.com/berita/baca/lt5f226379df52a/ini-

hak-wni-yang-jadi-korban-terorisme-di-luar-negeri/;

https:/ / www.bbc.com/indonesia/dunia-47578604;

https:/ / www.cnnindonesia.com/internasional/20160323113522-134-

119223/wni-jadi-korban-luka-dalam-ledakan-di-brussels;

https:/ / regional.kompas.com/read/2020/10/11/22143121/jenazah-

wni-korban-sandera-abu-sayyaf-disambut-tangis-

keluarga?page=all;

https:/ /lpsk.go.id/berita/detailberita/2740 